\title{
高強度鋼材を活用した全体崩壊形鋼架構の変形性能向上に関する研究 STUDY ON DEFORMATION CAPACITY IMPROVEMENT OF THE STEEL FRAME
WITH TOTAL COLLAPSE MECHANISM USING HIGH STRENGTH STEELS
}

\author{
福間智 之*, 多賀謙蔵**
}

Tomoyuki FUKUMA and Kenzo TAGA

\begin{abstract}
In recent years, attention to pulse type earthquakes that cause large displacement responses are concentrated. Some of them are predicted much higher than the level used in the current design, so it is promoted to set new seismic waves for design and to study about new design methods. As a way to reduce damage of buildings for such earthquakes, we propose the frame using high strength steels in column. In this case, it is difficult to avoid the column bases being plasticized in the ultimate state. We consider the column base models showing stable behaviors against excessive earthquake ground motion.
\end{abstract}

Keywords : Pulse Type Earthquake, High Strength Steel, Deformation Capacity, Damage Reduction, Column Base パルス性地震動, 高強度鋼材, 変形性能, 損傷低減, 柱脚

\section{1. はじめに}

近年, 建築物に大きな応答変位を生じさせるパルス性地震動への 注目が集まっている，その中には現在設計で用いる地震動の大きさ を上回ると予測されるものも多く, 新たな設計用地震動の設定並び に設計法に関する研究が進められている ${ }^{11}$.

架構内に制振部材を用いて大地震時に主架構の被害を最小限に抑 える損傷制御設計 ${ }^{2)}$ の考え方が高層建物を中心に一般化しつつある. また, 主架構の被害を抑えるために, 柱梁に高強度鋼材を用いて弾 性限変形を大きくすることが提案されている ${ }^{3), 4}$. 高強度鋼材の建築 構造材料としての実用化研究により, H-SA700 (780N/mm² 級鋼材) やSSS1000 (950N/mm² 級鋼材) が開発され, 実物件への適用も実現 している ${ }^{5)}$.これには, 高強度鋼材の溶接接合に関する研究開発の 成果が活かされているが，高強度鋼材同士の溶接接合には制限があ るのが現状であり，普及に当たっては更なる工夫が必要とされると ころである ${ }^{6}$. 溶接を用いない乾式工法も開発されているが例えば7), 接合できる断面の制約があり，必ずしも実用的とは言えない。これ に対して筆者らは, フランジが高強度鋼材, ウェブが普通鋼材の異 種鋼材 $\mathrm{H}$ 形断面柱と普通鋼材の梁を用いた梁降伏型架構を想定し, 高い耐震性能を付与することを検討してきた ${ }^{8) 100)}$.

柱に高強度鋼材を用いた場合, 終局状態における最下階柱脚の塑
性化は望ましくない。これは, 高強度鋼材の降伏比が 1 に近い值を 示し, 普通鋼材に比べて塑性化後の耐力上昇による塑性化領域の広 がりが小さく, 塑性変形能力がそしいためである。高強度鋼材を使 用した柱母材の塑性化を避けるために，図 1 に示すような鉄骨基礎 梁を先行降伏させる方法を用いた実施例 ${ }^{5) か ゙ あ る も の の ， こ の よ う ~}$ な機構を設けにくい場合の柱脚設計には課題が残されている.一方, 現状で既に実用化されている柱脚設計の考え方のひとつとして，伸 び能力を付与したアンカーボルトを引張り降伏させる方法がある. また，鋼管型ダンパーやベースプレートを用いてエネルギー吸収を 図る柱脚等が提案されている ${ }^{11), 12)}$. しかし，いずれも大きな軸力が 作用する場合には, 柱母材が曲げ圧縮状態で塑性化せざるを得ない. これらを考慮すると, 過大入力に対しても安定した挙動を示すこと ができれば，柱脚母材の塑性化を許容する考え方もあり得る.

以下, 本研究では高層建物を対象として, はじめにフランジが高 強度鋼材(H-SA700), ウェブが普通鋼材(SN490)の異種鋼材 H 形断面 柱と普通鋼材(SN490)の梁を用いた上部架構を「高耐震性架構」と呼 び，その有用性について検討する. 次いで埋め込み柱脚または地下 階に連続する架構の 1 階柱脚を想定して過大入力に対しても安定 した挙動を示すことが期待できる柱母材の柱脚モデルを複数提案し 比較検討を行う.
本論文は文献 8)～10)をもとに加筆・再構成したものである.

* 神戸大学大学院工学研究科建築学専攻 大学院生

** 神戸大学大学院工学研究科建築学専攻 教授·博士 (工学)
Grad. Stud., Dept. of Architecture, Faculty of Engineering, Kobe University Prof., Dept. of Architecture, Faculty of Engineering, Kobe University, Dr.Eng. 


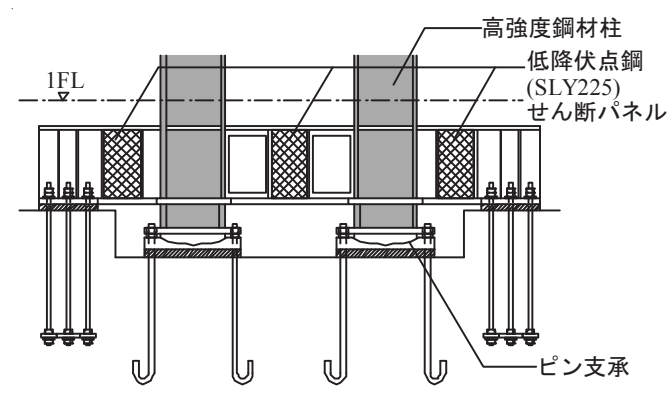

図 1 高強度鋼材を柱に用いた実施例 ${ }^{5)}$ の柱脚部

\section{2. 高強度鋼材を用いた高耐震性架構}

\section{1 想定する大振幅のパルス性地震動}

内陸直下型地震を想定したパルス成分を含む設計用地震動として, 上町断層帯地震を想定した 3 段階の設計用入力地震動が設定されて いる ${ }^{1)}$. 大阪市中心部の区域で定義されているレベル 3B の地震動に ついて, 高層建築物の最大層間変形角応答を略算的に表す $R_{\max }$ 応答 スペクトル 13)（減衰定数 $h=2 \% ） を$ 図 2(a)に示す.

また設計初期段階や応答比較評価等に有効な検討用地震動として, 上町断層帯地震で発生するパルス性地震動を簡潔・明瞭に模擬した 正弦波 1 波のパルス波 ${ }^{14}$ ) (パルス周期 $T_{p}=1 \sim 3 \mathrm{~s}$, レベル $3 \mathrm{~A}$ : 最大 速度 $\left.V_{\max }=100 \mathrm{~cm} / \mathrm{s}, 3 \mathrm{~B}: V_{\max }=125 \mathrm{~cm} / \mathrm{s}, 3 \mathrm{C}: V_{\max }=150 \mathrm{~cm} / \mathrm{s}\right)$ が提示さ れている ${ }^{1)}$. レベル $3 \mathrm{~B}$ の正弦波パルス入力時の $R_{\max }$ 応答スペクト ル $(h=2 \%)$ を図 2(b)に示す。これらから 1 次固有周期が 1 秒程度以 上の多層建物はレベル 3B のパルス性地震動に対して, 固有周期に かかわらず $1 / 50 \mathrm{rad}$ 程度の大きな層間変形角を生じることがわかる

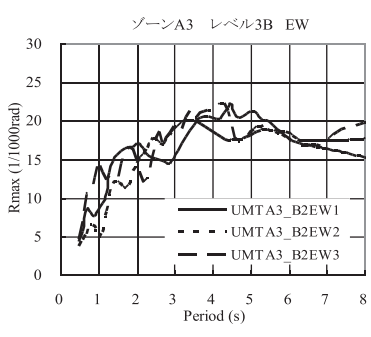

(a) 選定地震動

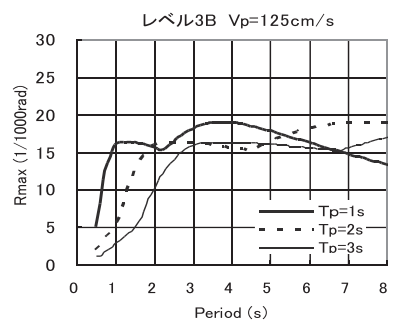

(b) 正弦波パルス
図 2 レベル $3 \mathrm{~B}$ 地震動の $R_{\max }$ 応答スペクトル $(h=2 \%)$ 1)

\section{2 高耐震性架構の概要}

一般に建物の損傷を低減させるために架構の剛性を増大させて変 形を抑えることは有効であるが，2.1 節に示した地震動を対象とす る場合，剛性を増大させても一定の変位応答が生じるため，損傷低 減効果は小さい。また，パルス性の入力に対して，付加減衰による 大きな効果は期待できない. 従って, 架構の損傷を低減するために は，弾性限変形を大きくすることが有効である，架構の剛性を低減 させて弾性限変形を大きくすると, 中小地震時や風荷重時に対する 性能が低下寸ることにつながるため好ましくはない，架構の剛性を 同等としつつ，耐力を増大させる必要があり，高強度鋼材はその目 的に適う典型的な材料である。

パルス入力と高強度鋼材の特徵を踏まえると，大振幅のパルス性 地震動に対しても架構の損傷を低減するための目指すべき方向性が 次のように考えられる. (1)架構の剛性を現状と同等としつつ, 弾性
限変形を大きくするために高強度鋼材の活用が有効である. (2)設計 上の想定を超える過大入力を考慮すると, 柱梁すべてを塑性変形能 力の乏しい高強度鋼材と寸ることは好ましくなく，梁には塑性変形 能力を持たせるべきである。(3)施工性，経済性を考慮し，高強度鋼 材の溶接接合は避けたい。ここからフランジが高強度鋼材, ウェブ が普通鋼材の異種鋼材 $\mathrm{H}$ 形断面柱と普通鋼材の梁を用いた架構が考 えられる. 柱材を断面性能に強い方向性を有する $\mathrm{H}$ 形断面に限定寸 ることは, 架構計画上の重要な前提条件となるものであるが，架構 計画によっては角形鋼管柱による場合と比較して必ずしも不経済に なるとは限らない 15),16)，現状では高強度鋼材を有効活用するための 必要条件の一つと考える. 図 3 亿高耐震性架構の模式図と損傷低減 の概念図を示す，大振幅のパルス性地震動により $1 / 50 \mathrm{rad}$ 程度の最 大層間変形角が生じるとすれば，現行のクライテリアを満たす建物 （降伏層せん断力 $Q_{y}$ 時の層間変形角が $1 / 200 \mathrm{rad}$ 程度）の最大層塑 性率は 4 程度になるが，耐力を約 1.6 倍し弾性限変形を大きくする ことで 2.5 程度まで低減可能であると考えられる. この時, 耐力を 増大寸るために梁断面は大きくなるが，高強度鋼材を用いた柱によ って所要の耐力を確保しながら層剛性を同程度に調整する。図 3(b) 中の $\times$ 印は架構の変形能力が限界に近いこと， 一印は架構の変形能 力に余裕があることを表す。

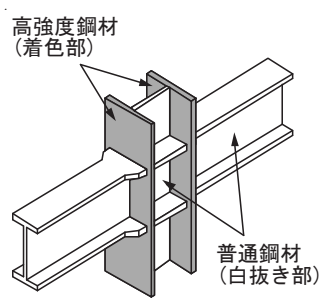

(a) 模式図

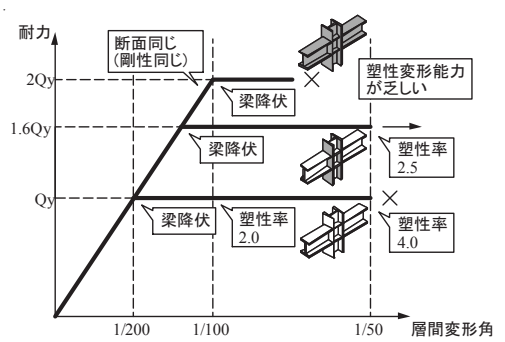

(b) 損傷低減の概念図

\section{図 3 高耐震性架構}

\section{3 高耐震化効果の検証方法}

まず，柱梁共に普通鋼材で構成した「初期モデル」を作成する. このモデルは現行のクライテリアを満たすよう設計する．次に層の 剛性を同等としつつ梁耐力を約 1.6 倍，柱のフランジを高強度鋼材 として柱梁耐力比を確保した「高耐震モデル」を作成する．さらに 比較用のモデルとして, 梁耐力は高耐震モデルと同等とし，層の剛 性が大きくなることを許容して，柱を普通鋼材として柱梁耐力比を 確保した「剛性増大モデル」を作成する，作成したモデルに正弦波 パルスを入力し, 損傷低減効果と費用対効果の観点から比較を行う.
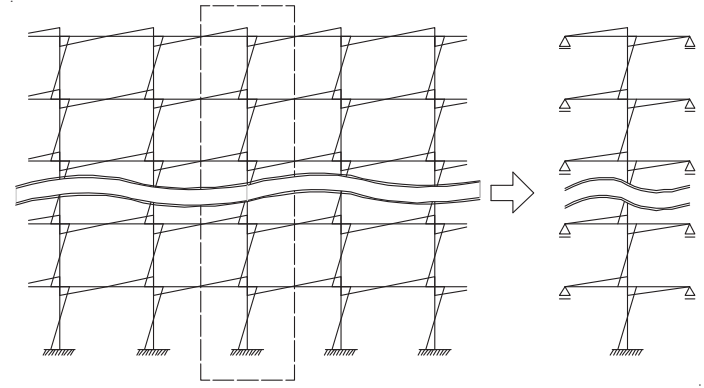

図 4 魚骨形モデル概念図 ${ }^{17}$ 
多層骨組の基本的な構造要素であるラーメン架構の基礎的な弾塑 性挙動を把握することを目的として, 解析対象は水平方向に無限均 等な部材配置を持つ多層多スパン平面骨組から単スパン分を取り出 した図 4 の破線で囲んだ多層魚骨形部分骨組とする。この骨組は梁 降伏型多層多スパン骨組の崩壊挙動の基本的性質を調べる上で標準 的なモデルと考えられる ${ }^{17)}$.

\section{4 解析用建物モデルの設計条件}

解析用の建物モデルとして 20，30，40 層の魚骨形モデルを作成す る. 崩壊機構は梁降伏型の全体崩壊形として, フロアモーメント分 配法を用いて塑性設計を行う。柱梁ともに反曲点位置は部材中央と する. 梁スパンは $6 \mathrm{~m}$, 柱の負担面積は $50 \mathrm{~m}^{2}$ と想定する. 第 2 種地 盤, 地域係数 $Z=1.0$, 標準せん断力係数 $C_{0}=1.0$, 形状特性係数 $F_{e s}=1.0$, 構造特性係数 $D_{s}=0.4$, 層せん断力の高さ方向の分布を $A_{i}$ 分布とした 時の層せん断力を必要保有水平耐力とする. 柱梁耐力比は 1.5 以上 を確保する. 高強度鋼材の最大板厚は $50 \mathrm{~mm}$ ，普通鋼材は $100 \mathrm{~mm}$ と する.その他の設計条件を以下に示す.

・階高 : 最上階, 中間階 $=3.75 \mathrm{~m}$, 最下階 $=4 \mathrm{~m}$

- 負担重量：最上階，最下階 $=10 \mathrm{kN} / \mathrm{m}^{2} \times 50 \mathrm{~m}^{2}=500 \mathrm{kN}$, 中間階 $=8 \mathrm{kN} / \mathrm{m}^{2} \times 50 \mathrm{~m}^{2}=400 \mathrm{kN}$

- 鋼材種 : 普通鋼材 $=\mathrm{SN} 490 \mathrm{~B}$ (降伏応力 $\sigma_{y}=325 \mathrm{~N} / \mathrm{mm}^{2}$ ), 高強度鋼材 $=\mathrm{H}-\mathrm{SA} 700\left(\sigma_{y}=700 \mathrm{~N} / \mathrm{mm}^{2}\right)$

・部材ランク : 梁 $=\mathrm{FA}$, 柱 $=\mathrm{FC}$ 以上

・スラブの合成効果を想定して，梁の曲げ剛性増大率 ${ }_{g} \varphi_{b}$ を決定す る ${ }^{18)}$. 初期モデルでは ${ }_{g} \varphi_{b}=2.0$ とする. 高耐震モデルの梁耐力を大 きくする層については ${ }_{g} \varphi_{b}=1.6$ とする. これは初期モデルと高耐震 モデルでスラブによる梁の剛性増加分は変わらず，鉄骨部分のみ剛 性が増加するものと仮定して相対的に計算した時の平均值である.

・高耐震モデルにおけるフランジに高強度鋼材を用いた異種鋼材 $\mathrm{H}$ 形断面柱の耐力評価には，軸力とせん断力の影響を考慮した全塑性 曲げ而力評価式を用いる ${ }^{19)}$ 。 また, ウェブが軸力により全面降伏し ないよう, せん断降伏が先行しないよう断面を決定する.

・初期モデルの梁断面は必要保有水平耐力をちょうど満足する程度 に設定しており，応答解析時の変形はクライテリアを満足できてい ない.そのため, 架構の耐力と剛性への影響が小さいオイルダンパ 一を付加することを想定して，各層の減衰定数を変化させることで 変形がクライテリアを満足するモデルを作成する。一般的に上層部 は曲げ変形が卓越し，ダンパーの効果が小さくなることを考慮して 下層ほど減衰定数值を高く設定する．試行錯誤の結果定めた各モデ ルの 1 次の減衰定数 $h(\%)$ の変化を表 1 に示す. 減衰の種類は部材の 初期剛性比例型とする.

検討に用いる入力地震動を以下に示す.

・観測地震動（以下，観測波）

(1)El Centro 1940 NS, (2)Hachinohe 1968 NS, (3)Taft 1952 EW - 平成 12 年建設省告示第 1461 号に定める地震動（以下，告示波）

(1)Hachinohe EW 位相, (2)Tohoku NS 位相,

(3)JMA Kobe NS 位相，(4)ランダム位相

観測波は最大速度 $V_{\max }$ で基準化する. レベル 1 地震動では $V_{\max }=$ $25 \mathrm{~cm} / \mathrm{s}$, レベル 2 地震動では $V_{\max }=50 \mathrm{~cm} / \mathrm{s}$ とする. 告示波は, 表層 地盤による増幅率を一律 1.25 倍とし, レベル 2 で速度応答スペクト
ル $S_{v}=100 \mathrm{~cm} / \mathrm{s}$ 程度 $(h=5 \%)$ となる地震波を用いる. 図 5 に使用す る地震波の $S_{v}(h=5 \%)$ を示す (告示波は Hachinohe 位相のみ表示).

解析用建物モデルが満たすべき最大層間変形角 $R_{\max }$ と最大層塑性 率 $\mu_{\max }$, 弾性部材についての設計クライテリアを表 2 に示す.

表 1 減衰定数 $h$ の変化

\begin{tabular}{|c|c|c|c|c|c|}
\hline \multicolumn{2}{|c|}{20 層モデル } & \multicolumn{2}{c|}{30 層モデル } & \multicolumn{2}{c|}{40 層モデル } \\
\hline 階 & $h(\%)$ & 階 & $h(\%)$ & 階 & $h(\%)$ \\
\hline & & & & $31 \sim 40$ & 2 \\
\hline $16 \sim 20$ & 2 & & & $21 \sim 30$ & 3 \\
\hline $11 \sim 15$ & 3 & $26 \sim 30$ & 2 & $11 \sim 20$ & 4 \\
\hline $1 \sim 10$ & 4 & $1 \sim 25$ & 4 & $1 \sim 10$ & 5 \\
\hline
\end{tabular}

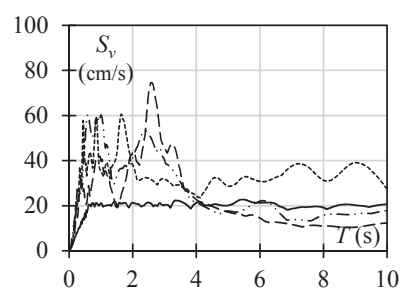

(a) レベル 1 地震動

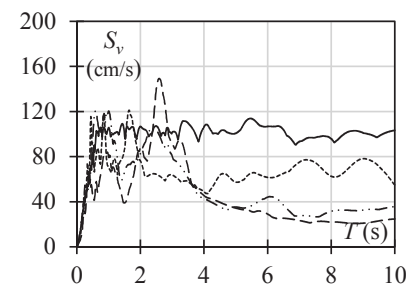

(b) レベル 2 地震動

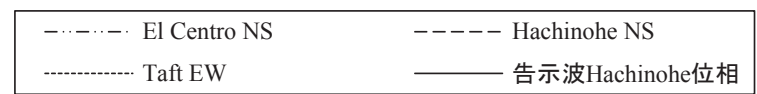

図 5 設計用入力地震動の速度応答スペクトル $(h=5 \%)$

表 2 設計クライテリア

\begin{tabular}{cccc}
\hline & $R_{\max }(\mathrm{rad})$ & $\mu_{\max }$ & 弾性部材 \\
\hline レベル 1 地震動 & $1 / 200$ & 1.0 & 全部材 \\
レベル 2 地震動 & $1 / 100$ & 2.0 & 最下階柱脚以外の柱 \\
\hline
\end{tabular}

\section{5 解析用建物モデルデータ}

モデル作成，解析には汎用解析ソフト SNAP Ver.6 を用いる.

解析に用いた梁材の応力-ひずみ関係はひずみ硬化係数 $\beta=0.01$ の バイリニア型とし，履歴則は移動硬化モデルとしている．柱材につ いては 3.1 節に準ずる。また，パネル降伏が先行しないように必要 に応じてパネル補強を行うことを前提としており，解析モデルでは パネルゾーンはモデル化していない.

作成した建物モデルの固有周期(s)を表 3 に示す。高耐震モデルは 剛性を同等として設定したため初期モデルとほぼ周期が等しく, 剛 性増大モデルは初期モデルより周期が短いモデルとなっている.

表 3 建物モデルの固有周期(s)

\begin{tabular}{|c|c|c|c|c|c|c|c|c|c|}
\hline & \multicolumn{3}{|c|}{20 層モデル } & \multicolumn{3}{|c|}{30 層モデル } & \multicolumn{3}{|c|}{40 層モデル } \\
\hline & 1 次 & 2 次 & 3 次 & 1 次 & 2 次 & 3 次 & 1 次 & 2 次 & 3 次 \\
\hline 初期 & 2.29 & 0.88 & 0.54 & 3.26 & 1.25 & 0.77 & 4.30 & 1.67 & 1.02 \\
\hline 高耐震 & 2.29 & 0.88 & 0.54 & 3.26 & 1.26 & 0.77 & 4.30 & 1.69 & 1.03 \\
\hline 剛性増大 & 1.96 & 0.76 & 0.47 & 2.80 & 1.09 & 0.67 & 3.72 & 1.45 & 0.90 \\
\hline
\end{tabular}

以下，特記なき限り 30 層モデルの場合を例に検討結果を示す. 20，40 層モデルについても概ね同様の結果が得られている. 
表 4 断面リスト

\begin{tabular}{|r|c|c|c|c|c|}
\hline \multirow{2}{*}{ 層 } & \multicolumn{2}{|c|}{ 初期 } & \multicolumn{2}{|c|}{ 高耐震 } & 剛性增大 \\
\hline 30 & 梁 & 柱 & 梁 & 柱 & 柱 \\
\hline $2500 \times 200 \times 9 \times 16$ & H- $492 \times 465 \times 15 \times 20$ & H- $500 \times 200 \times 9 \times 16$ & H- $492 \times 465 \times 15 \times 20$ & H- $492 \times 465 \times 15 \times 20$ \\
25 & H- $600 \times 200 \times 12 \times 25$ & H- $512 \times 475 \times 25 \times 30$ & H- $700 \times 250 \times 12 \times 22$ & H- $502 \times 425 \times 25 \times 25$ & H- $532 \times 485 \times 35 \times 40$ \\
20 & H- $700 \times 250 \times 12 \times 25$ & H- $542 \times 485 \times 35 \times 45$ & H- $800 \times 300 \times 14 \times 25$ & H- $512 \times 485 \times 35 \times 30$ & H- $562 \times 495 \times 45 \times 55$ \\
15 & H- $700 \times 300 \times 14 \times 25$ & H- $562 \times 485 \times 35 \times 55$ & H- $800 \times 350 \times 16 \times 28$ & H- $522 \times 495 \times 45 \times 35$ & H- $582 \times 510 \times 60 \times 65$ \\
10 & H- $700 \times 350 \times 16 \times 25$ & H- $582 \times 495 \times 45 \times 65$ & H- $800 \times 350 \times 16 \times 36$ & H- $532 \times 505 \times 55 \times 40$ & H- $602 \times 515 \times 65 \times 75$ \\
5 & H- $700 \times 350 \times 14 \times 28$ & H- $592 \times 505 \times 55 \times 70$ & H- $800 \times 400 \times 19 \times 32$ & H- $552 \times 505 \times 55 \times 50$ & H- $622 \times 520 \times 70 \times 85$ \\
1 & H- $700 \times 350 \times 16 \times 28$ & H- $592 \times 505 \times 55 \times 70$ & H- $800 \times 400 \times 16 \times 32$ & H- $552 \times 495 \times 45 \times 50$ & H- $622 \times 520 \times 70 \times 85$ \\
\hline
\end{tabular}

代表階として 5 層ごとの断面リストを表 4 に示す. 剛性増大モデ ルの梁断面は高耐震モデルと同じである。高耐震モデルは初期モデ ルに比べ, 梁断面は大きく, 柱断面は小さくなっている.

図 6 に高耐震化に関する指標として, 保有水平耐力 $Q_{u}$ と降伏層 間変形角 $R_{v}$ を示す.ここで $Q_{u}$ はある層の最大層間変形角が $1 / 100 \mathrm{rad}$ に達するまで, $A_{i}$ 分布による水平荷重を用いて静的増分解析を行っ た時の層せん断力とする。 $R_{y}$ は全ての層の最大層間変形角が 1/100rad を超えるまで行った増分解析結果から得られるスケルトン カーブをトリリニア近似した結果の第一折れ点変位から求めている. トリリニア近似は，初期勾配と最大変位時の接線勾配（第 3 勾配） を決めた後，スケルトンカーブと近似折れ線に囲まれた面積が等し くなるように第 2 勾配を複数算出し，その内面積が最も小さくなる ものを採用している．初期モデルは必要保有水平耐力をちょうど満 足する程度，高耐震モデルと剛性増大モデルはその 1.6 倍程度の耐 力となっている．また，初期モデルと剛性増大モデルに比べて高耐 震モデルは弾性限変形が大きくなっていることが確認できる.

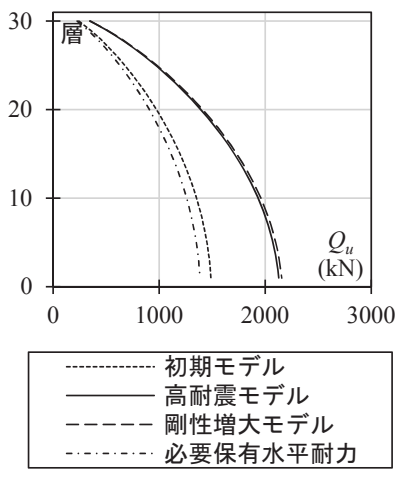

(a) 保有水平耐力

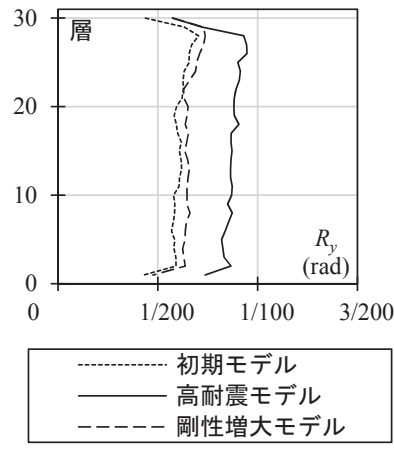

(b) 降伏層間変形角

\section{図 6 高耐震化に関する指標}

以下，解析結果は，複数の地震波を入力した結果の最大值の包絡 線を示す.一つの地震波により図に示寸応答が生じるとは限らない.

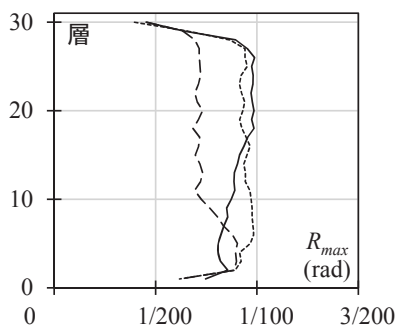

(a) 最大層間変形角

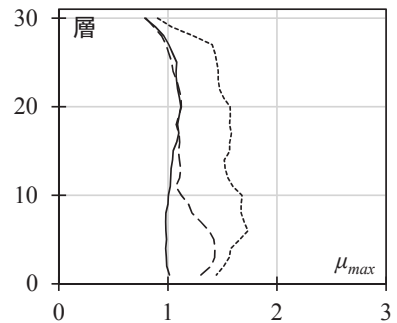

(b) 最大層塑性率

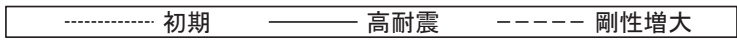

図 7 レベル 2 地震動の応答解析結果
図 7 にレベル 2 地震動に対する $R_{\max }$ と $\mu_{\max }$ を示す。ここで，層塑 性率の基点は $R_{y}$ と寸る. どのモデルも表 2 に示した設計クライテリ アを満足することが確認できる.

\section{6 正弦波パルスに対する損傷低減効果}

作成したモデルに正弦波パルスを入力し，層と部材のレベルで比 較を行う。正弦波パルスは上町断層帯地震の最大級レベルを想定し たものとして，レベル $3 \mathrm{C}\left(V_{\max }=150 \mathrm{~cm} / \mathrm{s}\right)$ のもの ${ }^{1)}$ を使用する。 ま た，検討用地震動として提案されている正弦波パルスのパルス周期 は 1 3 秒であるが ${ }^{14)}$, 建物モデルの固有周期が長周期であることを 考慮し，4 秒まで検討を行うこととする. 入力地震動の応答スペク トルの山谷による影響を小さくする目的で, パルス周期の刻みは 0.5 秒ごととする. 図 8 に使用する地震波の $S_{v}(h=5 \%)$ を示す。また, 図 9 に正弦波パルスに対する $R_{\max }$ と $\mu_{\max }$ を示す。ここでは 20, 40 層 モデルの結果も併せて示す。

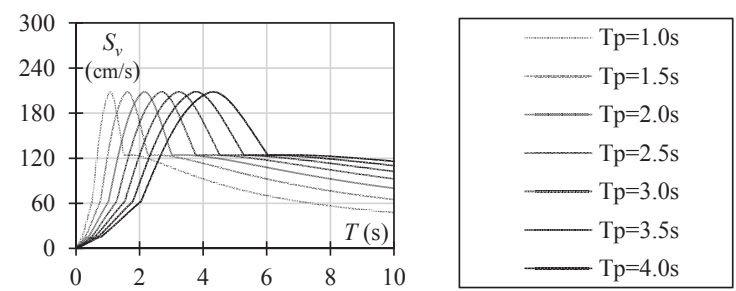

図 8 正弦波パルスの速度応答スペクトル $(h=5 \%)$
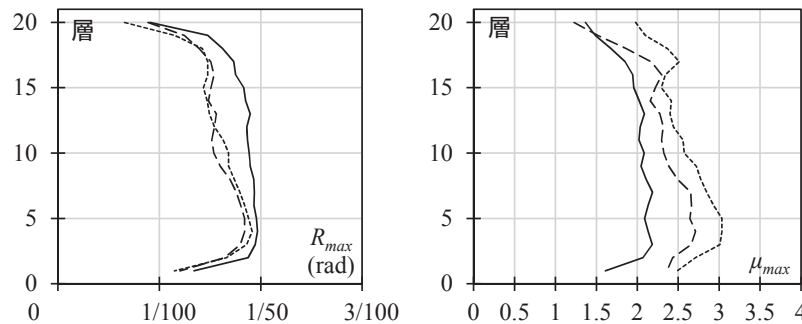

(a) 最大層間変形角（20 層）

(b) 最大層塑性率（20 層）
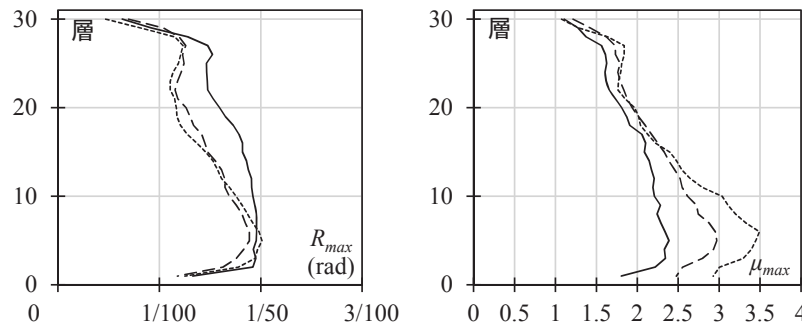

(c) 最大層間変形角 (30 層)

(d) 最大層塑性率（30 層）
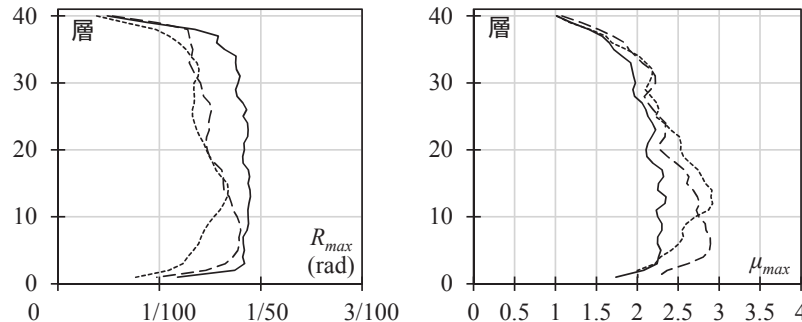

(e) 最大層間変形角 (40 層)

(f) 最大層塑性率（40 層）

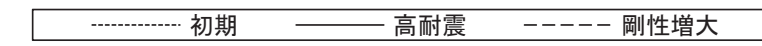

図 9 正弦波パルスに対する層レベルの応答 
40 層初期モデルを除き, どのモデルも $1 / 50 \mathrm{rad}$ 程度の最大層間変 形角が生じており，固有周期によらず一定の大きな応答変位を生じ るというパルス性地震動の特徴が確認できる. 40 層初期モデルにつ いては $T_{p}=5.0 \mathrm{~s}$ の正弦波パルスを入力すると $1 / 50 \mathrm{rad}$ 程度の最大層間 変形角が生じた。最大層塑性率に着目すると, 初期モデルは下層部 に損傷が集中しているのに対して高耐震モデルは損傷集中が抑えら れており，大きな効果が確認できる。変形が若干大きくなっていた 上層部についても最大層塑性率は低減されており，ほぼ全層にわた って最大層塑性率の低減が確認できる. 剛性増大モデルは 20, 30 層 モデルで若干の低減が見られるものの大きな効果は確認できない.

正弦波パルスに対する最大梁端回転角 ${ }_{g} \theta_{\max }$ と最大梁端塑性率 ${ }_{2} \mu_{\max }$ を図 10 に示す. 高耐震モデルは下層部で, 最大梁端回転角, 最 大梁端塑性率ともに低減されており，部材レベルにおいても高耐震 化による損傷低減効果が確認できる。ただし低減の程度は最大層塑 性率よりは小さい.

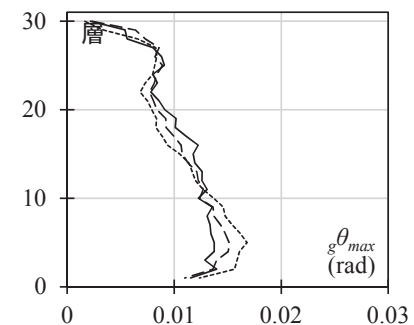

(a) 最大梁端回転角

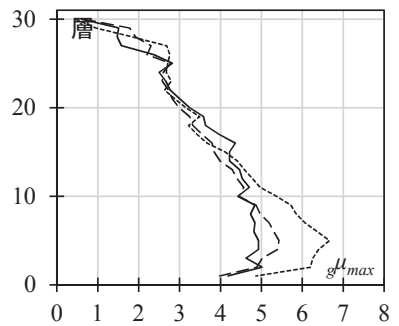

(b) 最大梁端塑性率

- 初期 高耐震 - - - - 剛性増大

図 10 正弦波パルスに対する部材レベルの応答

高耐震モデルの最下階柱脚では，正弦波パルスに対して柱に塑性 化が生じていた．塑性変形能力の乏しい高強度鋼材が塑性化するこ とは避けるべきであり, 第 3 章では最下階柱脚について検討を行う.

ダンパーによる付加減衰のない純ラーメン架構の性能を比較する ため, 一律 $h=2 \%$ とした場合のレベル 2 地震動と正弦波パルスに対 する 30 層モデルの最大層塑性率を図 11 に示す. ダンパーによる付 加減衰がある場合に比心゙，変形は大きくなっているが同等の高耐震 化による損傷低減効果が確認できる.

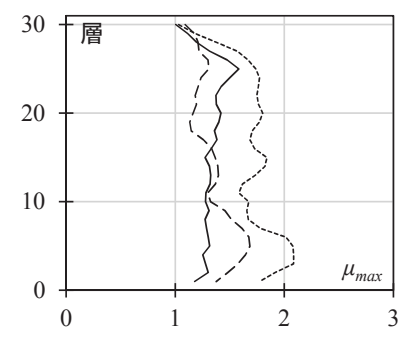

(a) レベル 2 地震動

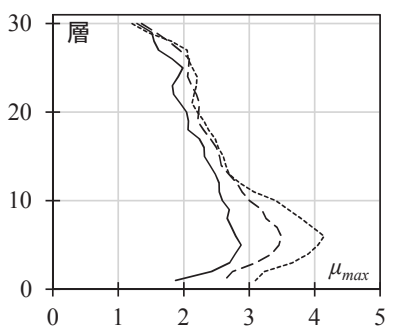

(b) 正弦波パルス
高耐震 - - - - 剛性増大

図 11 一律 $h=2 \%$ とした場合の最大層塑性率（30 層）

\section{7 費用対効果}

表 5 にコスト指標の初期モデルに対する比を示す。コスト指標は 「鋼材量 $\times$ 降伏応力度」で算定する。これは，加工費等も含めた鋼
材費が鋼材の強度に比例すると仮定することに相当する。一般に鋼 材自体の価格は強度に比例する程度であるが, 溶接難易度の差によ り加工費において強度比以上の価格差が生じる。本検討における高 耐震モデルは，高強度鋼材同士の溶接接合を必要としない架構方式 （普通鋼材の梁降伏型機構）並びに部材断面（ウェブを普通鋼材と する異種鋼材 $\mathrm{H}$ 形断面柱）を前提としているため，加工費の上昇は わずかであると考え，このような仮定を設けている．なお，柱フラ ンジに高強度鋼材，柱ウェブと梁に普通鋼材を用いた架構について は，柱部材および十字架構の試験体を用いた実験により，その適用 性が確認されている 19) 21).

初期モデルに比べ高耐震モデルも剛性増大モデルも 1.3 倍程度の コスト増となっている。一般的な高層鉄骨建築物の鉄骨工事費が全 体工事費に占める割合を $25 \%$ とすると全体工事費のコスト増は $7.5 \%$ 程度と言える. 高耐震モデルと剛性増大モデルでは耐力, コス トが同程度であるが，損傷低減効果は高耐震モデルの方が大きい.

表 5 コスト指標比（()内は鋼材量比）

\begin{tabular}{rccc}
\hline & 20 層 & 30 層 & 40 層 \\
\hline 高耐震/初期 & $1.34(0.99)$ & $1.33(0.97)$ & $1.33(0.96)$ \\
剛性増大/初期 & $1.30(1.30)$ & $1.30(1.30)$ & $1.30(1.30)$ \\
\hline
\end{tabular}

\section{3. 高耐震性架構の最下階柱脚}

\section{1 提案柱脚モデル}

以下,「柱脚」とは図 12 に示すような, 埋め込み柱脚または地下 階に連続する架構の 1 階柱脚を想定した時の鉄骨母材を表す.

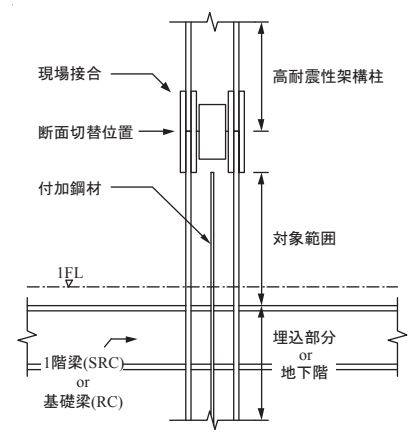

図 12 想定する柱脚形式

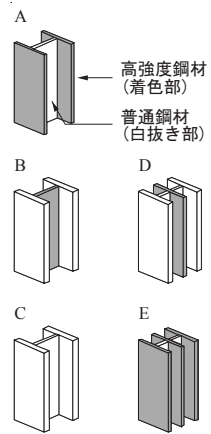

図 13 検討柱脚モデル
図 13 に検討を行う柱脚モデルの模式図を示す，白抜きの部分が 普通鋼材，着色部分が高強度鋼材を表す，高耐震性架構で用いられ ている柱断面をそのまま柱脚断面とする場合を比較基準用にモデル $\mathrm{A}$ とし, 提案する柱脚をモデル $\mathrm{B} \sim \mathrm{E}$ とする．基本的に普通鋼材は 塑性変形量, 高強度鋼材は弾性限界により各柱脚モデルの限界状態 を定義し，その限界状態に到達した時の挙動を調べることで比較を 行う。性能比較のため, 各モデルの断面は軸力を考慮した時の全塑 性耐力 $M_{p n}$ をそろえて設定する，なお，モデル $\mathrm{D} ， \mathrm{E}$ の断面中央の 高強度鋼材を「付加鋼材」と呼ぶこととする。

限界状態の判定は MS(Multi Spring)モデル 22)を用いて行う. MS モ デルは, 軸力および 2 軸曲げを考慮した挙動を簡単に表現すること ができ, 骨組の応答解析にも簡単に適用できることから, 柱部材の モデルとして有効な解析モデルと言える. 図 14 に示すように部材 
の両端を弾塑性要素, 中央線材を弾性要素としてモデル化する. 断 面を複数の弾塑性軸バネに分割し, 各分割断面の断面積を各重心位 置に配置する. 個々の軸バネは「要素バネ」と呼ぶこととする. 弾 塑性要素にモデル化する領域の長さは降伏比の違い, フランジとウ エブの鋼材種の組み合わせ, 幅厚比ランクをパラメータとして最大 耐力時の変形を等価にするための平均的な值を算定した結果，フラ ンジが高強度鋼材の柱は部材長の 0.03 倍, フランジが普通鋼材の柱 は部材長の 0.08 倍として設定する. 断面の分割数は各モデルにより 異なるが，片側のフランジ，ウェブをそれぞれ 10 20 分割程度とし ている. 要素バネの応力-ひずみ関係は $\beta=0.01(\mathrm{SN} 490)$ または $\beta=0.001(\mathrm{H}-\mathrm{SA} 700)$ のバイリニア型とし, 履歴則は移動硬化モデルと している.

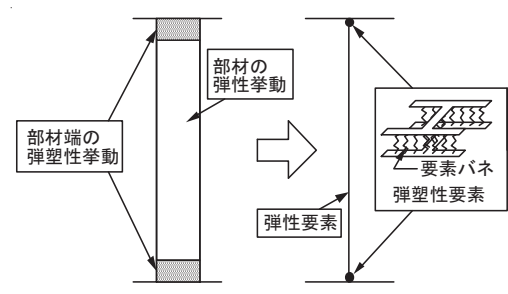

図 $14 \quad M S$ モデル概念図 ${ }^{22)}$

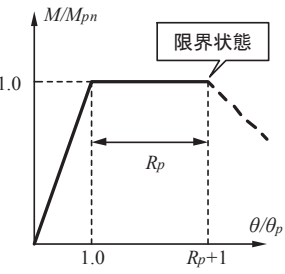

図 15 塑性変形倍率 23

\section{2 各柱脚モデルのねらいと限界状態の仮定}

モデル A : 高層建物を対象とした場合，柱脚には常時比較的大き な圧縮軸力が作用する。 そのため变動軸力が支配的でない場合は, 引張側フランジが降伏することは考えにくい. よって, 圧縮側フラ ンジが降伏した時を限界状態とする。つまり MS モデルの片側のフ ランジの要素バネが降伏した時である.

モデル B : ウェブが高強度鋼材の場合, フランジに用いた普通鋼 材が降伏した後もウェブが弾性状態に保たれるため，ある程度の剛 性を保ち耐力が上昇し, その間にフランジの塑性化を許容できる. 限界状態は高強度鋼材であるウェブが塑性化を開始した時とする. つまり MS モデルのフランジに最も近いウェブの要素バネが降伏し た時である.

モデル C : 高強度鋼材を用いていないため降伏後も塑性変形能力 を期待できる，ただし，弾性部分がなくなると大変形後の残留ひず みが大きく生じてしまうという課題がある、鋼構造限界状態設計指 針・同解説 ${ }^{23)}$ を参照して図 15 に示寸部材の塑性変形倍率 $R_{p}$ を定め, これを超えた時を限界状態とする. 部材降伏時回転角 $\theta_{p}$ は全塑性回 転角ではなく，圧縮側フランジが降伏した時の回転角と寸る。これ は全塑性回転角よりわずかに小さな值となるが，安全側の評価であ ること, モデル A の限界状態と物理的に対応をさせられることから このように設定した. MS モデルによる限界状態判定は $\left(R_{p}+1\right) \theta_{p}$ 時 の片側のフランジの要素バネの変形によって行うこととする.

モデル D : フランジの塑性化を許容した上で高強度鋼材が降伏し た時を限界状態とするならば，高強度鋼材をできるだけ曲げによる ひずみの小さい断面の中央に集約させるのが効果的である．付加鋼 材の軸耐力を柱にかかる軸力と同程度に設定することで，高軸力下 においても塑性中立軸は断面中央付近にとどまり, 圧縮側フランジ の塑性化の進行が抑制される，そのため，片側のフランジが集中し て塑性化するモデル $\mathrm{C}$ と同等のひずみが生じるのは，より大きな変
形をした時であると考えられる。よって，MS モデルによる限界状 態判定は, 片側のフランジの要素バネの変形によって行うこととし, モデル C と同等になった時を限界状態とする。

モデル E : ウェブの中心に高強度鋼材を付加すると, 圧縮側フラ ンジが降伏もしくは局部座屈して軸岡性を堮失しても, 付加鋼材の 存在により部材としての曲げ剛性を喪失せず, 引張側フランジが降 伏するまで耐力の上昇を期待できるため，圧縮側フランジに用いた 高強度鋼材の塑性化を許容する. よって引張側フランジが降伏した 時を限界状態と寸る。つまり MS モデルの両側のフランジの要素バ ネが同時に降伏した時である。

\section{3 柱脚モデルの静的挙動検討}

モデル A の断面寸法を 2.5 節に示した建物モデルの平均的な值か ら決定し，モデル B E の断面寸法をモデル A の $M_{p n}$ にそろえて決定 する. 検討用断面の断面寸法と $M_{p n}(\mathrm{kNm})$, 軸力比 $n$ を表 6 に示寸. 高強度鋼材は表中に口で囲んで表し, 付加鋼材はフランジ厚の次に 「+幅×厚さ」で表記する。ここで，「幅」は両側の合計，ウェブの 厚さを含む寸法で示している．軸力は高層建物を想定して $10000 \mathrm{kN}$ とする，普通鋼材は FA ランク，高強度鋼材は FC ランク以上とす る.また，部材長を $4 \mathrm{~m}$ （反曲点中央）と仮定した時にせん断降伏が 先行しないよう, 対象軸力下で普通鋼材の全面降伏が生じないよう 断面を決定する. 付加鋼材のあるモデルは初めに, 負担軸力と付加 鋼材の降伏軸力が同程度となるように付加鋼材の寸法を決定する. その後, 全てのモデルで負担軸力下の曲げ耐力が同等になるように, フランジ寸法, ウェブ寸法の順に調整して断面を決定する. $M_{p n}$ をそ ろえるためにモデル B , C, D の断面せいはやや大きくなっている. 軸力比に大きな差は生じていない

\section{表 6 検討用柱脚断面}

\begin{tabular}{clcc}
\hline & \multicolumn{1}{c}{ 断面寸法 } & $M_{p n}(\mathrm{kNm})$ & $n$ \\
\hline A & $\mathrm{H}-500 \times 500 \times 50 \times 50$ & 7166 & 0.24 \\
B & $\mathrm{H}-580 \times 580 \times 40 \times 70$ & 7192 & 0.26 \\
$\mathrm{C}$ & $\mathrm{H}-580 \times 580 \times 60 \times 80$ & 7156 & 0.26 \\
$\mathrm{D}$ & $\mathrm{H}-560 \times 560 \times 65 \times 70+400 \times 35$ & 7164 & 0.23 \\
$\mathrm{E}$ & $\mathrm{H}-525 \times 525 \times 50 \times 35+400 \times 35$ & 7135 & 0.24 \\
\hline
\end{tabular}

MS モデルによる限界状態判定を行うために骨組解析ソフト SNAP Ver.6，詳細検討を行うために有限要素解析ソフト ABAQUS CAE Ver.6.9-2 を用いて部材のモデル化を行う. $2 \mathrm{~m}$ の片持ち柱につ いてそれぞれ部材回転角 $\theta=0.04 \mathrm{rad}$ まで静的増分解析を行い, 部材 の復元力特性を把握する. SNAP については平面フレームで作成し, 局部座屈は考慮しない，付加鋼材についてはその面積を集約した要 素バネを断面中央に配置することでモデル化する. ABAQUS につい てはシェル要素で構成し，SNAP では再現が難しい局部座屈現象の 検討を行う。初期不整は座屈固有值解析の結果得られる局部座屈モ ード形状に従って与えることとし,その最大值をフランジ幅の $1 / 200$ とする. 各要素の応力-ひずみ関係は $\beta=0.01(\mathrm{SN} 490)$ または $\beta=0.001$ (H-SA700)のバイリニア型とし, 履歴則は移動硬化モデルとしている. 各モデルが限界状態に到達するまでの変形能力を比較する。 SNAP による静的増分解析結果を材端モーメント $M(\mathrm{kNm})$-部材回転 
角 $\theta(\mathrm{rad})$ 関係で図 16 に示す. 圧縮側フランジが降伏した時の点を $\triangle$ 印で, 限界状態に到達した時の点を×印でプロットし, 対応するモ デルの名前を併記する．モデル A については圧縮側フランジが降伏 した時を限界状態としているため， $\triangle$ 印と×印は重なっている.

モデル B, C, D は剛性が大きいため, モデル A に比べて弾性限 変形は小さくなっているが, 塑性変形量は大きくなっている. ただ し，モデル B が限界状態に達する変形量は増加していない，モデル $\mathrm{E}$ はモデル A に比べて少し早めに圧縮側フランジが降伏するが，若 干ながら変形能力が向上している，また，高強度鋼材によって限界 状態が決まるモデル A， B， E に比べ，普通鋼材によって限界状態が 決まるモデル C，D の方が高い変形能力を持つことがわかる。つま り, 3.2 節において定義した限界状態によると, 恋形能力を高めるに は，フランジに普通鋼材を使用し，高強度鋼材によって限界状態が 決まることを避けるのが有効であると言える.

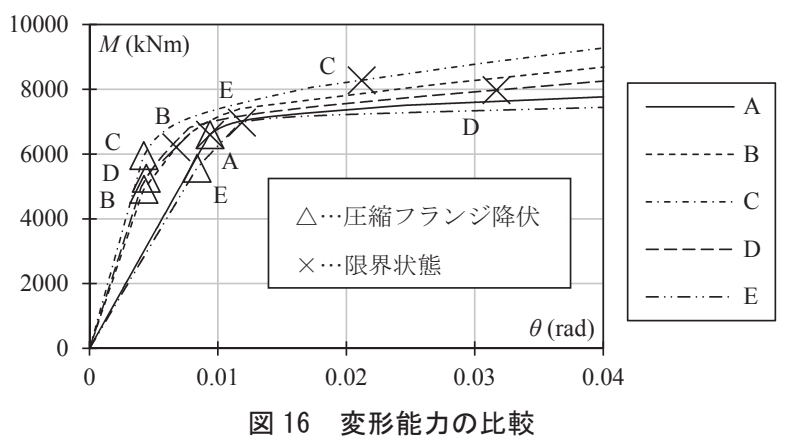

高層建物を想定した大きな長期軸力を設定しているため，大変形 後の残留ひずみに対する検討を行う. ABAQUS を用いた有限要素解 析により, 長期軸力を与えたまま繰り返し強制変形させた後の軸縮 みを検討する。ここでは, 自由端側の断面中央節点の材軸方向変位 を軸縮みとする．繰り返し変形は，レベル 2 地震動を想定したもの として $\pm 1 / 100 \mathrm{rad}$ の強制変位を 4 サイクル, 設計対象として推奨され ているパルス性地震動を想定したものとして $1 / 50 \mathrm{rad} の$ 強制変位を 1 サイクルとする.

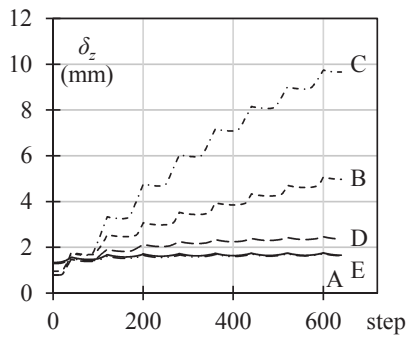

(a) レベル 2 地震動想定

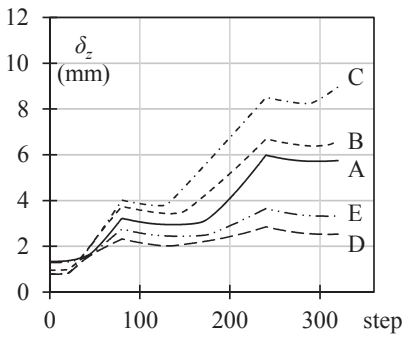

(b) パルス性地震動想定

\section{図 17 軸縮み}

図 17 に軸縮み $\delta_{z}$ を示す。モデル C は全断面が塑性化するため最 も大きな軸縮みが生じているのに対して，モデル A， B，D，E は弾 性状態の高強度鋼材が断面の一部に残るため軸縮みが抑えられてい ることが確認できる．また，モデル A はレベル 2 地震動想定時に比 べてパルス性地震動想定時に軸縮みが大きくなっているのに対して,
モデル D， E はほとんど進展していないことが確認できる。ここか ら, 大振幅のパルス性地震動に対して軸縮みを抑えるためには断面 中央に高強度鋼材を付加することが効果的であることがわかる.

パルス性地震動の特徵を踏まえると, 強軸方向以外にも大きな強 制変位を生じることが予想される，そこで ABAQUS を用いて強軸 方向に加え, 弱軸, $45^{\circ}$ 方向に静的増分解析を行う. その際, 圧縮側 の局部座屈発生状況ならびに,引張側のひずみの大きさを確認する. 各モデルの $M(\mathrm{kNm})-\theta(\mathrm{rad})$ 関係を図 18 に, 引張側最大ひずみ $\varepsilon_{\max }(\%)$ を表 7 に示寸. 図 18 から, どのモデルも $\theta=0.04 \mathrm{rad}$ まで顕著な耐力 劣化を引き起こすような局部座屈は生じていないため, 耐力劣化を 考慮しない SNAP の解析結果は限界状態まで妥当であると言える. また，各モデルが 3.2 節で想定した挙動を示すことを確認した. 強 軸方向変形時の引張側最大ひず夕は高強度鋼材が $5.0 \%$, 普通鋼材が $5.3 \%$ となっており, 文献 24)に示される一様伸びの平均的な值（HSA700 が 7\%程度，SN490 が 16\%程度）以下である。局所的な值で ある最大ひずみが局部的な変形集中が始まる一様伸び以下であるこ とから．柱母材が破断する可能性は低いと言える．また，弱軸方向 変形時には $\theta=0.04 \mathrm{rad}$ まで不安定現象は生じず， $45^{\circ}$ 方向変形時には モデル A， E で引張側ひずみが一様伸び程度まで生じている。

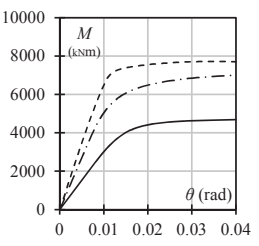

(a) モデル A

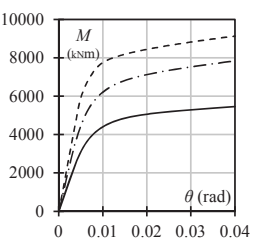

(d) モデル D

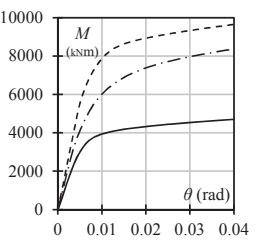

(b) モデル B

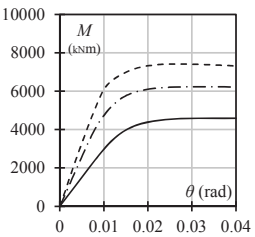

(e) モデル E

図 18 増分解析結果

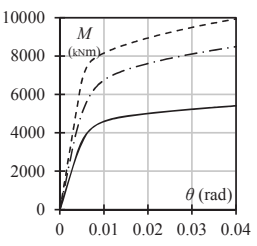

(c) モデル C

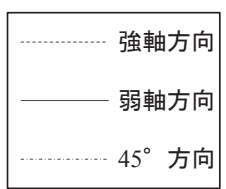

表 7 引張側最大ひずみ

\begin{tabular}{ccccccccc}
\hline & \multicolumn{3}{c}{ 普通鋼材 $\varepsilon_{\max }(\%)$} & & \multicolumn{3}{c}{ 高強度鋼材 $\varepsilon_{\max }(\%)$} \\
\cline { 2 - 3 } \cline { 7 - 9 } & 強軸 & 弱軸 & $45^{\circ}$ & & 強軸 & 弱軸 & $45^{\circ}$ \\
\hline $\mathrm{A}$ & 5.27 & - & 3.02 & & - & 5.05 & 8.37 \\
$\mathrm{~B}$ & 4.92 & 4.76 & 7.13 & & 2.73 & - & 1.81 \\
$\mathrm{C}$ & 3.40 & 5.06 & 7.36 & & - & - & - \\
$\mathrm{D}$ & 5.06 & 4.81 & 7.15 & & - & 4.09 & 1.87 \\
$\mathrm{E}$ & 4.85 & - & 3.61 & & 4.99 & 5.39 & 8.60 \\
\hline
\end{tabular}

\section{4 柱脚モデルの動的挙動検討}

2.5 節に示した高耐震モデルに各柱脚モデルを適用して, 限界状 態に到達する時の地震動の入力レベルの大きさを考察する．正弦波 パルスの入力倍率を 0.1 刻みで変化させて, 各柱脚モデルが限界状 態に到達した時の入力倍率を「限界倍率」と呼ぶこととする．表 8 に 30 層モデルに適用する柱脚モデルの断面寸法と性能を示す. 表 示方法は表 6 と同様とする。 


\section{表 830 層モデル検討用柱脚断面}

\begin{tabular}{|c|c|c|c|}
\hline & 断面寸法 & $M_{p n}(\mathrm{kNm})$ & $n$ \\
\hline A & $\mathrm{H}-552 \times 495 \times 45 \times 50$ & 7411 & 0.30 \\
\hline B & H- $602 \times 570 \times 40 \times 75$ & 7423 & 0.30 \\
\hline $\mathrm{C}$ & H- $622 \times 575 \times 50 \times 85$ & 7401 & 0.31 \\
\hline $\mathrm{D}$ & $\mathrm{H}-592 \times 560 \times 45 \times 70+440 \times 40$ & 7394 & 0.28 \\
\hline E & $\mathrm{H}-532 \times 480 \times 50 \times 40+440 \times 40$ & 7438 & 0.27 \\
\hline
\end{tabular}

各柱脚モデルが限界状態に到達した時の解析結果として限界状態 判定を行う要素バネの荷重 $P(\mathrm{kN})$-変形 $\delta(\mathrm{mm})$ 関係の一例を図 19 に 示す．ここでは圧縮側を正で表示する．その時のパルス周期と入力 倍率を凡例に併記する．３.2節で定義した通り，モデル A，B，E は 要素バネの降伏の有無，モデル $\mathrm{C} ， \mathrm{D}$ は要素バネの変形量から限界 状態を判断した。

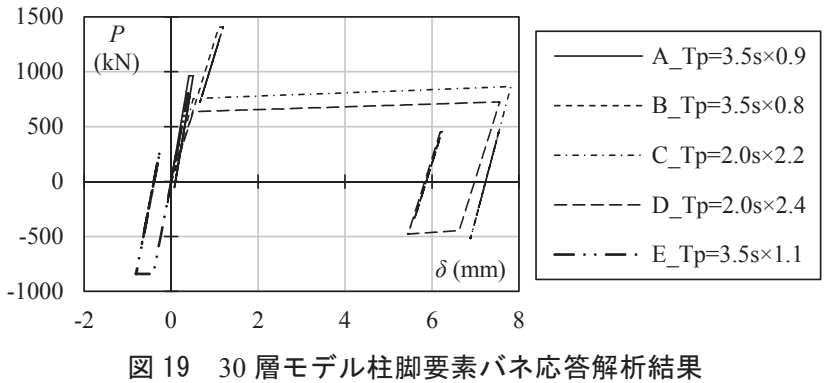

この方法で決定した各柱脚モデルの限界倍率を $20,30,40$ 層モデ ルについて図 20 に示寸. モデル C, D の限界倍率が特に大きく2 2.5 倍程度になっている. モデル D は付加鋼材の効果によりモデル C に 比べてフランジのひずみが低減され，限界倍率が大きくなっている ことが確認できる．モデル C は 3.3 節の検討により無視できない軸 縮みが生じることがわかっている. モデル B はモデル C, D と同様, フランジに普通鋼材を用いているが，引張側フランジが塑性化する 前に高強度鋼材であるウェブの塑性化が開始しており，高軸力下で は効果は期待できないと考えられる。モデル E については圧縮側フ ランジの高強度鋼材の塑性化を許容しており，限界倍率も大きくは 向上しないため望ましいモデルとは言えない，本研究の範囲ではモ デルDが望ましい柱脚断面であると言える.

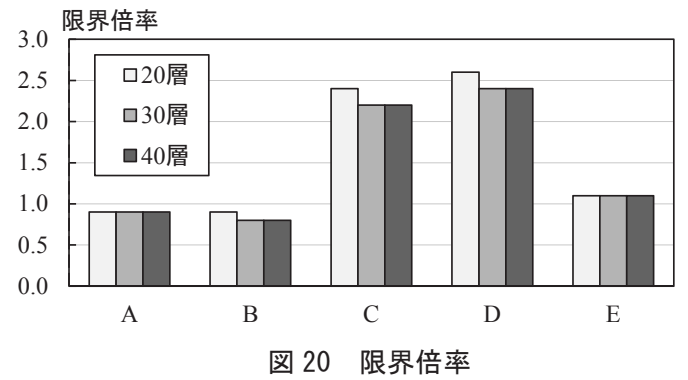

\section{5 架構の変形限界}

限界倍率の大きな柱脚モデルを適用寸ることで建物としての性能 が向上していることを確認する。そのために架構の変形限界に着目 する．柱脚が限界状態に到達する前に上部構造が変形限界に到達す
れば全体崩壊形としての建物の性能が発揮できていると言える．上 部構造の変形限界は, 大振幅のパルス性地震動を対象とした時の限 界状態の評価手法として提案されている部材耐力劣化限界とする. 判別指標として梁端塑性ヒンジ部の局部座屈による耐力劣化限界回 転角 $\theta_{d}$ を用いる ${ }^{25)}$.

$\theta_{d}$ は, 加藤，秋山モデル ${ }^{26)}$ による部材の $M-\theta$ 関係において, 最大 曲げモーメント $M_{\max }$ の 90\%あるいは全塑性曲げモーメント $M_{p}$ の ど ちらか大きい曲げモーメントに達した時の塑性回転角とする（図 21 参照)。このように定義した $\theta_{d}$ と，片側の累積塑性回転角応答との 比較により局部座屈による部材の耐力劣化の有無を判断することと されている ${ }^{25)}$. 本研究ではまず，各梁ごとに加藤，秋山モデル ${ }^{26)}$ よって $\theta_{d}$ を算定し，次いで 3.4 節の応答解析結果から得られる梁端 累積回転角との比較を行う。なおパルス入力を対象とした場合, 片 側の累積塑性回転角は最大回転角にほぼ等しい。
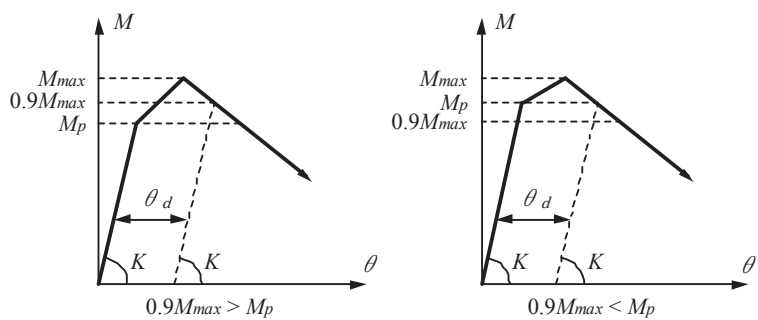

図 21 局部座屈による耐力劣化限界回転角 ${ }^{25)}$

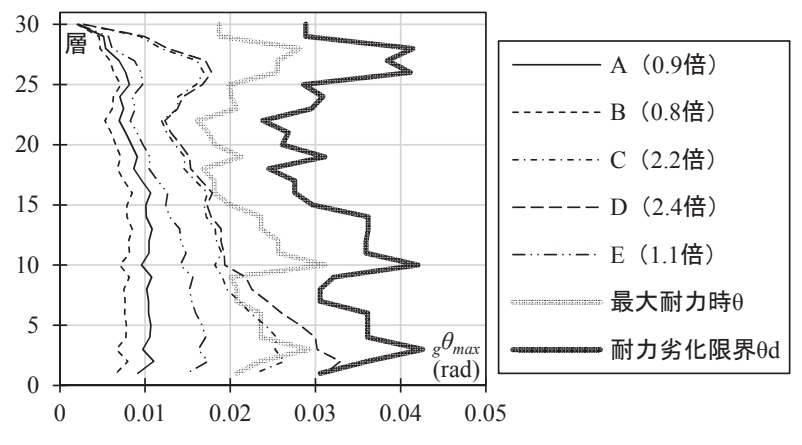

図 22 累積回転角, 限界回転角, 最大耐力時回転角

各柱脚モデルの限界倍率の正弦波パルスを入力した時の梁端累積 回転角（複数入力による結果の最大值の包絡線）と局部座屈による 耐力劣化限界回転角ならびに最大耐力時の回転角を重㸚たものを図 22 に示す，凡例に各モデルの限界倍率を併記する。モデル A の限界 倍率入力時（0.9 倍）の累積回転角は限界回転角まで余裕があり，柱 脚が早期に限界に達するため建物の性能が発揮しきれていない。こ れに対し，柱脚を限界倍率の大きなモデルにすることで累積回転角 は限界回転角に近付き，建物の性能がより発揮されていることがわ かる，最も限界倍率の大きいモデル D に注目寸ると，下層部で限界 回転角程度まで梁の変形が生じている，つまり，柱脚が限界状態に 到達する前に上部構造が変形限界に達し，全体崩壊形としての建物 の性能が発揮できていると言える。なお，今回の応答解析ではバイ リニア型（ $\beta=0.01$, 移動硬化モデル $)$ の復元力特性を用いているた め, 図 21 の負勾配の範囲では異なるものになるが, 応答解析結果は 最大耐力時の回転角を下層部で一部超える程度であり, 柱脚が限界 
状態に到達する前に上部構造が変形限界に到達することを確認する という観点からは，概衩妥当な評価ができていると考える.

\section{4. まとめ}

無限均等な部材配置を持つ多層多スパン平面骨組から単スパン分 を取り出した魚骨形モデルを用いて, 柱フランジに高強度鋼材 $(\mathrm{H}-$ SA700), 柱ウェブと梁に普通鋼材(SN490)を用いた架構の損傷低減 効果を示した.また費用対効果の観点からも評価を行った. 次いで, 過大入力に対しても安定した挙動を示す柱脚モデルを提案した．有 限要素モデル及び MS モデルにより各柱脚モデルの静的挙動を把握 した上で，限界状態に至る地震動の入力倍率により性能評価を行っ た．高層建物の中柱を想定し，柱脚断面には幅厚比の小さなものを 用いてパルス性の過大入力を対象とした検討を行った結果，以下の 知見を得た.

（1）柱フランジに高強度鋼材，柱ウェブと梁に普通鋼材を用いた架 構は柱梁ともに増厚した架構に比べて, 耐力, コストが同程度 であるが，損傷低減効果は大きい。

(2) 柱フランジに高強度鋼材，柱ウェブと梁に普通鋼材を用いた架 構を用いることで，現行の基準で設計された建物に比べて大幅 なコストの増大を伴うことなく, 耐震性能の高い建物が設計可 能であると言える.

（3）全体崩壊機構を形成し，限界状態に至る地震動の入力倍率を大 きくするには，最下階柱脚において，高強度鋼材の塑性化を避 けて変形能力を持たせることが効果的である.

(4) ウェブ，フランジとも普通鋼材で構成した $\mathrm{H}$ 形断面の中央に高 強度鋼材を付加した柱脚断面を用いることにより，上町断層帯 地震の最大級とされるレベルの 2 倍程度まで安定した挙動を示 すことが可能となる．また，柱脚が限界状態に到達する前に上 部構造が変形限界に到達し，全体崩壊形としての建物の性能が 発揮できる。

ただし，柱脚に関する知見は，高強度鋼材は弾性限界，普通鋼材 は塑性変形量から限界状態を定義した場合のものである．鋼材種の 組み合わせ，変動軸力の影響，柱脚断面の幅厚比が大きい場合につ いても今後検討を進めたい。一方，柱フランジに高強度鋼材，柱ウ エブと梁に普通鋼材を用いた架構については，柱部材および十字架 構の試験体を用いた実験により，その適用性が確認されている ${ }^{191211}$. 今後は，柱脚部の挙動も実験により明らかにしたい．

\section{謝辞}

本研究は, 科学研究費・基盤研究(c)(No.25420580)の助成を受けた. また, 研究室の卒業生である小早川拓氏, 䅖山貴志氏の研究成果を もとに検討を行った。ここに記して感謝の意を表す。

\section{参考文献}

1) 多賀謙蔵, 亀井功, 角彰, 近藤一雄, 林康裕, 宮本裕司, 井上一朗 : 上町 断層帯地震に対する設計用地震動ならびに設計法に関する研究, その 1 , その 2, 日本建築学会大会学術講演梗概集, B-1, pp.127-130, 2011.8

2) 和田章, 岩田衛, 清水敬三, 安部重孝, 川合広樹 : 建築物の損傷制御設 計，丸善， 1998

3) 中井政義, 中村豊, 前田祥三, 田中勉, 浅井英克, 鈴木庸介 : 高強度鋼を 用いた巨大地震に対する主架構無損傷設計法の提案，日本建築学会構造
系論文集，Vol.76，No.666，pp.1443-1451，2011.8

4) 竹内徹, 大山翔也，石原直：制振部材を付加した高強度鋼架構の繰返し 変形性能, 日本建築学会構造系論文集, Vol.75, No.655, pp.1671-1679, 2010.9

5) 多賀謙蔵，入江敏彦，川畑友弥，福田浩司，一戸康生，橋田知幸，沼田俊 之, 秦泉寺稔子, 白沢吉衛, 吉澤幹夫, 多田元英 : $1000 \mathrm{~N}$ 級鋼 $\left(950 \mathrm{~N} / \mathrm{mm}^{2}\right.$ 鋼）の建築構造物一の適用性について，その 16 実構造物の設計例，日 本建築学会大会学術講演梗概集, C-1, pp.629-630, 2010.7

6) 川畑友弥, 一戸康生, 福田浩司, 佐々木正道, 沼田俊之, 橋田知幸, 藤平 正一郎，甲津功夫，多田元英，桑原進，多賀謙蔵：建築用 $1000 \mathrm{~N}$ 級

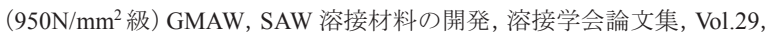
No.2, pp.114-124, 2011.12

7) 佐藤篤司，木村慧，吹田啓一郎，井上一朗：建築構造用高強度鋼材 $\mathrm{H}-$ SA700A を用いた柱梁材を弾性に留める乾式接合法の開発, 日本建築学 会構造系論文集, Vol.74, No.646, pp.2355-2363, 2009.12

8) 小早川拓, 三木佑斗, 多賀謙蔵：高強度鋼材の利用による高而震性構造 に関する研究，鋼構造年次論文報告集，Vol.21，pp.510-515，2013.11

9) 䅖山貴志，小早川拓，多賀謙蔵：鋼構造建物の耐震性能向上における高 強度鋼材の活用に関する研究, 鋼構造年次論文報告集, Vol.22, pp.338-345, 2014.11

10) 福間智之, 多賀謙蔵 : 大振幅地震動に対する鋼構造建築物柱脚部の損傷 低減に関寸る研究，鋼構造年次論文報告集，Vol.23，pp.228-235，2015.11

11) 向出静司, 井本大貴, 長山暢宏 : 鋼構造露出柱脚に適用する鋼管型ダン パー開発のための基礎的研究, 日本建築学会構造系論文集, Vol.77, No.678, pp.1329-1338, 2012.8

12) 緑川光正, 小豆畑達哉, 石原直, 和田章 : 地震応答低減のためベースプレ 一トを浮き上がり降伏させた鉄骨架構の動的挙動, 日本建築学会構造系 論文集，No.572，pp.97-104，2003.10

13）亀井功, 佐藤浩太郎, 林康裕：モーダル解析によるパルス波地動に対す る多自由度系の層間変形角応答特性, 日本建築学会構造系論文集, Vol.75, No.649, pp.567-575, 2010.3

14）鈴木恭平, 川辺秀憲, 山田真澄, 林康裕 : 断層近傍のパルス性地震動特性 を考慮した設計用応答スペクトル，日本建築学会構造系論文集，Vol.75， No.647, pp.49-56, 2010.1

15) 高木次郎, 大崎純：耐震架構全体分散型と外周集約型の鋼構造事務所建 物の構造性状比較, 日本建築学会構造系論文集, Vol.80, No.715, pp14691477, 2015.9

16）多賀謙蔵，小原英：多方向の入力を考慮した場合の箱形断面柱と $\mathrm{H}$ 形断 面柱の耐震性能比較に関する研究, 日本建築学会大会学術講演梗概集, C-1, pp1035-1036, 2012.9

17) 上谷宏二, 田川浩: 梁降伏型骨組の動的崩壊過程における変形集中現象, 日本建築学会構造系論文集, No.483, pp.51-60, 1996.5

18）日本建築学会：各種合成構造設計指針・同解説，丸善，2010.11

19) 遠藤千尋，大和田尚吾，多賀謙蔵，北岡聡，一戸康生：異種鋼材 H 形断 面柱の耐力評価に関する研究: 鋼構造年次論文報告集, Vol.21, pp.345-352, 2013.11

20) 大和田尚吾，木下康仁，浅田勇人，多賀謙蔵，田中剛：780N/mm ${ }^{2}$ 級鋼を 用いた異種鋼材 $\mathrm{H}$ 形断面柱の部材性能に関寸る研究，鋼構造年次論文報 告集, Vol.22, pp.710-715, 2014.11

21）加藤彰浩，山下怜士，浅田勇人，多賀謙藏，田中剛：780N/mm ${ }^{2}$ 級鋼を用 いた異種鋼材 $\mathrm{H}$ 形断面を柱材とする十字架構の力学特性, 鋼構造年次論 文報告集，Vol.23，pp.438-445，2015.11

22) 石井正人, 斉藤安生, 浅野美次, 堀井昌博: マルチスプリングモデルの特 性, その 1, その 2, 日本建築学会大会学術講演梗概集, B-1, pp.383-386, 1997.9

23) 日本建築学会 : 鋼構造限界状態設計指針・同解説，丸善，2010.2

24）岩田善裕, 石原直, 向井昭義, 西山功, 青木博文 : 鋼材の素材引張試験に おける一様伸びと破断伸びの関係, 日本建築学会構造系論文集, Vol.78, No.683, pp.223-232, 2013.1

25) 日本建築学会 : 大振幅地震動と建築物の耐震性評価-巨大海溝型地震 - 内 陸地震に備えて-, 丸善, 2013.9

26) 加藤勉, 秋山宏, 帯洋一: 局部座屈を伴う $\mathrm{H}$ 形断面部材の変形, 日本建築 学会論文報告集，No.257，pp.49-58，1977.7 


\title{
STUDY ON DEFORMATION CAPACITY IMPROVEMENT OF THE STEEL FRAME WITH TOTAL COLLAPSE MECHANISM USING HIGH STRENGTH STEELS
}

\author{
Tomoyuki FUKUMA* and Kenzo TAGA**
}

\author{
* Grad. Stud., Dept. of Architecture, Faculty of Engineering, Kobe University \\ ** Prof., Dept. of Architecture, Faculty of Engineering, Kobe University, Dr.Eng.
}

In recent years, attention to pulse type earthquakes that cause large displacement responses are concentrated. Some of them are predicted much higher than the level used in the current design, so it is promoted to set new seismic waves for design and to study about new design methods. To reduce damage of buildings against large earthquake, it has been considered to increase the elastic limit deformation using high strength steels in columns and girders. In this study, on the contrary, we propose the frames using hybrid H-section columns consist of flange with high strength steels and web with conventional strength steels, and conventional girders. In the case of using the high strength steel in columns, it is difficult to avoid the column bases of the first story being plasticized in the ultimate state. So, we consider the column base models showing stable behaviors against excessive earthquake ground motion.

In Chapter 2, we show the damage reduction effect of the frames using hybrid columns and conventional girders by using fish bone shaped models that are taken out of single-spans from multi-layer multi-span flat frames have uniform members. In addition, it was also evaluated from the cost effectiveness. In Chapter 3, we propose the column base models which show stable behaviors against excessive earthquake ground motion. After understanding the static behavior by finite element models and multi-spring models, we evaluated the performance during earthquake by defining the index called the limit magnification. With H-SA700 as a high strength steel and SN490 as a conventional strength steel, assuming inner columns of high-rise buildings, using column base sections of small width-thickness ratio, we obtained the following results.

(1) The frames using hybrid columns and conventional girders, compared to the frames using conventional columns and girders composed of thickened plate, have same degree of the proof stress and the cost, and also reduced more damage. (2) By using the frame using hybrid columns and conventional girders, we can design a high earthquake resistance building without an increase in significant cost compared to a building designed with existing standards.

(3) To increase the limit magnification in the column bases of the first story against excessive input, it is effective to have a deformation capacity without plasticizing of high strength steels of hybrid columns.

(4) The model obtained by adding a high strength steel in the center of the H-section composed of conventional steel can show stable behavior against about 2 times the level which is the largest Uemachi fault zone seismic. In addition, the superstructure reaches the deformation limit before the column base reaches the limit state. As a result, the performance of the building as the total collapse mechanism can be sufficiently exhibited.

In the future, we are going to research the combination of steel species, effects of varying axial force, the case of using column base sections of large width-thickness ratio. On the other hand, Research on the application of the frames using hybrid columns and conventional girders is under way by experiments using the test piece of the column members and the cross structures. In addition, we are going to research the behavior of the column bases by experiments. 